\title{
Człowiek według Martina Heideggera
}

\section{Remigiusz Lucjan Król, Analiza kategorii bycia i człowieka w koncepcji filo- zoficznej Martina Heideggera, Wydawnictwo Naukowe Sub Lupa, Truskaw 2017, ss. 303.}

$\mathrm{K}^{\mathrm{s}}$ siążka Remigiusza Lucjana Króla zatytułowana Analiza kategorii bycia i człowieka w koncepcji filozoficznej Martina Heideggera podejmuje - jak wskazuje jej tytuł - ontologiczno-antropologiczne aspekty Heideggerowskiej filozofii. Praca składa się z pięciu rozdziałów. Jej celem jest przeanalizowanie: 1) bytu i bycia jako możliwości kategorii filozoficznych człowieka (rozdział pierwszy), 2) kategorii filozoficznej bycia-w-świecie (rozdział drugi), 3) kategorii bycia jestestwa (rozdział trzeci), 4) egzystencji jako kategorii ujawniania bycia (rozdział czwarty), 5) struktury czasowości jestestwa (rozdział piąty). Owe analizy, jak zaznacza Król, mają kulminować poznaniem człowieka „w całej jego złożoności ontyczno-bytowej”.

Nie chcąc streszczać zawartości poszczególnych rozdziałów monografii Króla, skupię się przede wszystkim na uwagach krytycznych. Po pierwsze, rzuca się w oczy to, że w pracy tej znajduje się bardzo wiele obszernych cytatów, zarówno z samego Heideggera (głównie z Bycia i czasu²), jak i jego komentatorów (zwłasz-

${ }^{1}$ R.L. Król, Analiza kategorii bycia i człowieka w koncepcji filozoficznej Martina Heideggera, Wydawnictwo Naukowe Sub Lupa, Truskaw 2017, s. 23.

${ }^{2}$ M. Heidegger, Bycie i czas, tłum. B. Baran, Wydawnictwo Naukowe PWN, Warszawa 1994. 
cza Krzysztofa Michalskiego ${ }^{3}$ czy Otto Pöggelera ${ }^{4}$ ). Oczywiście, nie chodzi tu o to, że powoływanie się na rozpoznania innych badaczy, w tym bezpośrednie przytaczanie ich spostrzeżeń, jest czymś w praktyce naukowej niestosownym. Przeciwnie, zazwyczaj świadczy to o znajomości literatury przedmiotu oraz umiejętności trafnego i uzasadnionego jej wykorzystania. Idzie więc raczej o to, że proporcja samodzielnie sformułowanych poglądów do tych jedynie „przepisanych” została tutaj znacznie i rażąco zachwiana. Lwią część rozprawy Króla stanowią bowiem obszerne cytaty, nierzadko pozostawione przy tym bez autorskiego, krytycznego komentarza ${ }^{5}$. Można odnieść wrażenie, że autor, rekonstruując filozofię Heideggera, nie zajmuje własnego stanowiska, że nadmiernie „chowa” się za dobrze już znanymi jej interpretacjami. W tym sensie jego książka zyskuje walor przeglądowy, jednak wnosi niewiele nowej jakości do ogólnego stanu badań nad myślą Martina Heideggera.

Po wtóre, omawiana monografia nie jest dopracowana redakcyjnie. Zauważalny jest bowiem brak konsekwencji zarówno w zapisie przypisów, jak i końcowej bibliografii. Autor nie dba o spójną, jednolitą metodę, odnotowując źródła cytowanych przez siebie opracowań. Niekiedy podaje nazwę wydawnictwa oraz imię i nazwisko tłumacza danej publikacji, innym razem całkowicie o tym zapomina; zupełnie dowolnie i niekonsekwentnie stosuje też zapis „tłum.”, „przeł.” czy „przekł.” Ponadto, książka Króla zawiera liczne „literówki”, w tym w tytułach przywoływanych prac oraz w nazwiskach ich autorów (np. ss. 167; 248; 255; 270-272; s. 23, przypis 25; s. 125, przypis 18; s. 143, przypis 42). Co więcej, autor mylnie (i w niewłaściwy dla naukowych standardów sposób) przypisuje Heideggerowi słowa Krzysztofa Michalskiego, nie odróżniając konstatacji niemieckiego filozofa od wypowiedzi jego komentatora. Dla przykładu, na stronie 153 Król pisze, że Heidegger twierdzi „to i tamto”, po czym następuje obszerny cytat z pracy Heidegger i filozofia współczesna Michalskiego. Owa hermeneutyczna subtelność polega więc na tym, że to nie Heidegger uważa „to i tamto”, lecz Michalski tak sądzi, interpretując Heideggera.

Powyższe uwagi nie pomniejszają wszakże poznawczej wartości książki Króla. Jej zaletą jest bowiem ukazanie hermeneutyczno-egzystencjalnych wątków filozofii Heideggera, w tym zwrócenie uwagi na problematykę ludzkiego sposobu bycia-w-świecie (problem trwogi, troski, rozumienia, czasowości, bycia-ku-śmierci). Jak wiadomo, miejsce człowieka w refleksji autora Bycia i czasu nie jest jednoznaczne. Heidegger, pozostając częściowo pod wpływem Wilhelma Diltheya, mówi bowiem

${ }^{3}$ K. Michalski, Heidegger i filozofia współczesna, PIW, Warszawa 1978.

${ }^{4}$ O. Pöggeler, Droga myślowa Martina Heideggera, tłum. B. Baran, Czytelnik, Warszawa 2002.

5 Na przykład: ss. 10-11, 13-14, 19, 36-37, 38-39, 40-43, 45-46, 48-49, 50-53, 63-64, 72-75, 81, 83-85, 94-96, 98-99, 103-104, 110-111, 129, 133-136, 141-145, 153-156, 168-169, 186-191, 196-204, 213-217, 219-223, 227-228, 230-237, 239, 243-244. 
o „faktyczności” ${ }^{\text {i } ~ „ f a k t y c z n y m ~ z ̇ y c i u ” 7, ~ k t o ́ r e ~ s t a n o w i ~ p u n k t ~ w y j s ́ c i a ~ j e g o ~ f i l o z o-~}$ fowania ${ }^{8}$. W Sein und Zeit, swym epokowym dziele, używa on natomiast pojęcia Dasein, które - zgodnie z polskim przekładem Bogdana Barana - najczęściej tłumaczy się jako ,jestestwo”. Szkoda jednak, że Król, eksponując związek „kategorii bycia i człowieka” w koncepcji Heideggera, pomija ważne intuicje zawarte we wczesnych pracach fryburskiego filozofa (poprzedzających wydanie Sein und Zeit). Wydaje się, że ich przybliżenie - w kontekście omawiania analityki egzystencjalnej z Bycia i czasu - mogłoby rzucić nieco więcej światła na Heideggerowskie rozumienie życia, bycia i człowieka oraz relacji między nimi. Szkoda również, że Król nie rozwija przekonania, iż Heidegger jawi się nie tylko jako twórca ontologii fundamentalnej, ale także jako jeden z „twórców egzystencjalizmu”9. Bliższe przyjrzenie się tej kwestii mogłoby okazać się niezwykle interesujące, choćby dlatego, że sam filozof nie identyfikował się z egzystencjalizmem ${ }^{10}$.

Nie sposób przy tym nie zauważyć, że Heidegger krytycznie oceniał antropologię filozoficzną, nie poświęcił jej również żadnego osobnego studium. Najwięcej uwag na jej temat znajdziemy przede wszystkim w rozprawie Kant a problem metafizyki (1929) - niemiecki filozof kontestuje tutaj dążenie antropologii filozoficznej do orzekania, czym jest prawda ${ }^{11}$. Niemniej jednak można odnieść wrażenie, że Heidegger - wbrew swoim deklaracjom - konstruuje swego rodzaju antropologię, w której pytanie o człowieka ściśle wiąże się z pytaniem o bycie ${ }^{12}$. Myśl tę doskonale uchwycili - dla przykładu - Jarosław Jagiełło czy Włodzimierz Lorenc, na

${ }^{6}$ M. Heidegger, Ontologia (Hermeneutyka faktyczności), tłum. M. Bonecki, J. Duraj, Wydawnictwo Rolewski, Toruń 2007.

7 M. Heidegger, Fenomenologia życia religijnego, tłum. G. Sowinski, Znak, Kraków 2002.

${ }^{8}$ Szerzej na ten temat zob.: M. Potępa, Fenomenologia faktycznego życia. Martin Heidegger, Genessis, Warszawa 2004; D. Sobota, Źródła i inspiracje Heideggerowskiego pytania o bycie, t. 2, Fundacja Kultury Yakiza, Bydgoszcz 2013, s. 109 nn.; R. Safranski, Ein Meister aus Deutschland. Heidegger und seine Zeit, Fischer Taschenbuch Verlag, Frankfurt am Main 2001; T. Kisiel, The Genesis of Heidegger's 'Being and Time’, University of California Press, Berkeley 1993.

${ }^{9}$ R.L. Król, Analiza kategorii bycia i człowieka..., s. 8.

${ }^{10}$ Por. M. Heidegger, List o humanizmie, tłum. J. Tischner, w: Znaki drogi, tłum. S. Blandzi i in., Wydawnictwo Spacja, Warszawa 1999, ss. 271-312.

${ }^{11}$ Por. M. Heidegger, Kant a problem metafizyki, tłum. B. Baran, PWN, Warszawa 1989, s. 233. Zob. także M. Heidegger, Czas światoobrazu, tłum. K. Wolicki, w: Drogi lasu, tłum. J. Gierasimiuk i in., Fundacja Aletheia, Warszawa 1997, ss. 76-80.

12 Szerzej na ten temat zob.: M. Drwięga, Człowiek w filozofii Martina Heideggera, „Kwartalnik Filozoficzny” 3/2012, ss. 43-67; idem, Kim jest człowiek? Studia z filozofii człowieka, Księgarnia Akademicka, Kraków 2013, ss. 157-203; W. Rymkiewicz, Ktoś i nikt. Wprowadzenie do lektury Heideggera, Wydawnictwo Uniwersytetu Wrocławskiego, Wrocław 2002; P. Dybel, Oblicza hermeneutyki, Universitas, Kraków 2012, ss. 301-309; M. Januszkiewicz, Heidegger i antropologia, w: J. Kowalewski, W. Piasek (red.), Antropologizowanie humanistyki, Instytut Filozofii Uniwersytetu Warmińsko-Mazurskiego, Olsztyn 2009, ss. 255-269; idem, Kim jestem ja, kim jesteś ty? Etyka, tożsamość, rozumienie, Wydawnictwo Poznańskie, Poznań 2012, ss. 174-187; idem, W poszukiwaniu sensu. Phronesis i hermeneutyka, Wydawnictwo Naukowe UAM, Poznań 2016, ss. 169-183. 
których ustalenia Król akurat się nie powołuje. A szkoda, bo wspomniani wyżej badacze szczegółowo przedstawiają interesujące Króla zagadnienia. Lorenc pisze tak oto: „człowiek i bycie jakoś do siebie przynależą, w związku z czym podstawowe zagadnienie filozofii, jakim jest dla Heideggera kwestia bycia, stanowi formę istotowego pytania o człowieka”" Jagiełło z kolei nadmienia: „pytanie o bycie jest prawidłowo postawionym pytaniem o człowieka: można śmiało powiedzieć, że w centrum pytania o bycie znajduje się człowiek, bo to właśnie on stanowi pierwotny horyzont zapytywania o bycie" ${ }^{14}$. W tym sensie pytanie o bycie implikuje zarazem pytanie o człowieka; lub inaczej: nie sposób filozoficznie pytać o bycie, nie pytając jednocześnie o człowieka: „bycie potrzebuje człowieka, a człowiek jest tylko wówczas człowiekiem, jeśli jest zakorzeniony w byciu”"15. Wydaje się, że Król, snując swoje rozważania, nie tylko pomija ważne (choćby tylko polskojęzyczne) opracowania na temat filozofii Heideggera, ale i nie do końca wykorzystuje intelektualny potencjał tkwiący w pracach wymienionych przez niego w bibliografii.

Książka Analiza kategorii bycia i człowieka w koncepcji filozoficznej Martina Heideggera podejmuje najważniejsze aspekty filozofii Heideggera zorientowanej wokół problemu bycia i człowieka. Ma ona charakter przeglądowy i - pomimo sygnalizowanych wyżej jej niedoskonałości - może stanowić przyczynek do pogłębionej refleksji nad hermeneutyczno-egzystencjalnym wymiarem myśli Heideggerowskiej. Jest też ona dowodem na to, że filozofia autora Bycia i czasu nadal inspiruje, stając się przedmiotem studiów wielu współczesnych badaczy.

\section{Literatura}

Drwięga M., Człowiek w filozofii Martina Heideggera, „Kwartalnik Filozoficzny” 3/2012.

Drwięga M., Kim jest człowiek? Studia z filozofii człowieka, Księgarnia Akademicka, Kraków 2013.

Dybel P., Oblicza hermeneutyki, Universitas, Kraków 2012.

Heidegger M., Bycie i czas, tłum. B. Baran, Wydawnictwo Naukowe PWN, Warszawa 1994.

Heidegger M., Czas światoobrazu, tłum. K. Wolicki, w: Drogi lasu, tłum. J. Gierasimiuk i in., Fundacja Aletheia, Warszawa 1997.

Heidegger M., Fenomenologia życia religijnego, tłum. G. Sowinski, Znak, Kraków 2002. Heidegger M., Kant a problem metafizyki, tłum. B. Baran, PWN, Warszawa 1989.

Heidegger M., List o humanizmie, tłum. J. Tischner, w: Znaki drogi, tłum. S. Blandzi i in., Wydawnictwo Spacja, Warszawa 1999.

Heidegger M., Ontologia (Hermeneutyka faktyczności), tłum. M. Bonecki, J. Duraj, Wydawnictwo Rolewski, Toruń 2007.

${ }^{13}$ W. Lorenc, Hermeneutyczne koncepcje człowieka. W kręgu inspiracji Heideggerowskich, Wydawnictwo Naukowe Scholar, Warszawa 2003, s. 71.

${ }^{14}$ J. Jagiełło, Niedokończony spór o antropologię filozoficznq (Heidegger-Plessner). Studium historyczno-analityczne, Wydawnictwo IFiS PAN, Warszawa 2011, s. 87.

${ }^{15}$ Ibidem, s. 88. 
Jagiełło J., Niedokończony spór o antropologię filozoficznq (Heidegger-Plessner). Studium historyczno-analityczne, Wydawnictwo IFiS PAN, Warszawa 2011.

Januszkiewicz M., Heidegger i antropologia, w: J. Kowalewski, W. Piasek (red.), Antropologizowanie humanistyki, Instytut Filozofii Uniwersytetu Warmińsko-Mazurskiego, Olsztyn 2009.

Januszkiewicz M., Kim jestem ja, kim jesteś ty? Etyka, tożsamość, rozumienie, Wydawnictwo Poznańskie, Poznań 2012.

Januszkiewicz M., W poszukiwaniu sensu. Phronesis i hermeneutyka, Wydawnictwo Naukowe UAM, Poznań 2016.

Kisiel T., The Genesis of Heidegger's 'Being and Time', University of California Press, Berkeley 1993.

Król R.L., Analiza kategorii bycia i człowieka w koncepcji filozoficznej Martina Heideggera, Wydawnictwo Naukowe Sub Lupa, Truskaw 2017.

Lorenc W., Hermeneutyczne koncepcje człowieka. W kręgu inspiracji Heideggerowskich, Wydawnictwo Naukowe Scholar, Warszawa 2003.

Michalski K., Heidegger i filozofia współczesna, PIW, Warszawa 1978.

Pöggeler O., Droga myślowa Martina Heideggera, tłum. B. Baran, Czytelnik, Warszawa 2002.

Potępa M., Fenomenologia faktycznego życia. Martin Heidegger, Genessis, Warszawa 2004.

Rymkiewicz W., Ktoś i nikt. Wprowadzenie do lektury Heideggera, Wydawnictwo Uniwersytetu Wrocławskiego, Wrocław 2002.

Safranski R., Ein Meister aus Deutschland. Heidegger und seine Zeit, Fischer Taschenbuch Verlag, Frankfurt am Main 2001.

Sobota D., Źródła i inspiracje Heideggerowskiego pytania o bycie, t. 2, Fundacja Kultury Yakiza, Bydgoszcz 2013. 
